Vol. 1, No. 1, Desember 2020

\title{
PENDAMPINGAN PENYUSUNAN PROSEDUR OPERASIONAL BAKU BIDANG KEUANGAN MENUJU TATAKELOLA RUMAH SAKIT UNIVERSITAS YANG BAIK
}

\author{
Sapto Hendri ${ }^{1}$, Wirawan Suhaedi ${ }^{2}$, Siti Atikah ${ }^{3}$, Ahmad Taufik ${ }^{4}$ \\ 1,2,3,Fakultas Ekonomi dan Bisnis, Universitas Mataram, NTB \\ ${ }^{4}$ Fakultas Kedokteran Universitas Mataram, NTB \\ saptohendri9@unram.ac.id
}

Article History:

Received: -

Revised: -

Accepted: -

\begin{abstract}
Standard operating procedure (SOP) is a series of written instructions regarding the administrative implementation process which includes the time and method of implementation, as well as the implementing party. SOP is a reference or guideline for employees in carrying out activities and avoiding irregularities. University hospitals have an obligation to carry out efficient and effective administration of finance. To achieve this goal, a common perception and procedure is needed to carry out an activity. This is by compiling and establishing a financial administration SOP especially in this hospital. Mentoring was carried out in eight months using a discussion and interview approach. Employees related to the financial sector will be targeted for assistance. The results of discussions and interviews are compiled into a standard guideline and set by the hospital leadership.
\end{abstract}

Abstrak: Salah satu langkah dalam mewujudkan kualitas pelayanan yang efektif dan efisien adalah menyelenggarakan dan melaksanakan prosedur operasional baku, yang selanjutnya akan disingkat sebagai $P O B$. $P O B$ merupakan serangkaian instruksi tertulis mengenai proses penyelenggaraan administrasi yang meliputi waktu dan cara pelaksanaan, serta pihak yang melaksanakan. $P O B$ menjadi acuan atau pedoman bagi pegawai dalam melaksanakan kegiatan dan terhindar dari penyimpangan. Rumah sakit Universitas memiliki kewajiban untuk menyelenggarakan administrasi bidang keuangan yang efisien dan efektif. Untuk mencapai tujuan tersebut, dibutuhkan kesamaan persepsi dan prosedur untuk melaksanakan suatu kegiatan. Hal ini dengan menyusun dan menetapkan $P O B$ administrasi keuangan khususnya di rumah 
Sapto Hendri, dkk: Pendampingan Penyusunan Prosedur Operasional Baku Bidang........

sakit ini. Pendampingan dilaksanakan dalam delapan bulan menggunakan pendekatan diskusi dan wawaancara. Pegawai yang terkait dengan bidang keuangan akan dijadikan target pendampingan. Hasil diskusi dan wawancara, disusun menjadi suatu pedoman baku dan ditetapkan oleh pimpinan rumah sakit.

Keywords: Standard Operating Procedures, hospital, financial administratives.

Kata kunci: Prosedur Operasional Baku, rumah sakit, administrasi keuangan 


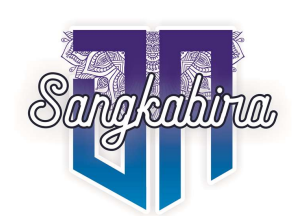

Vol. 1, No. 1, Desember 2020

\section{PENDAHULUAN}

Salah satu langkah dalam mewujudkan kualitas pelayanan yang efektif dan efisien adalah menyelenggarakan dan melaksanakan pengendalian internal. Pengendalian internal bertujuan untuk mencapai tujuan-tujuan yang telah ditetapkan (De La Cruz, 2018). Pengendalian internal salah satunya dilaksanakan dengan menyusun prosedur operasional baku, yang selanjutnya akan disingkat sebagai POB. POB berisi serangkaian instruksi tertulis mengenai proses penyelenggaraan administrasi yang terdiri dari waktu dan cara pelaksanaan, serta pihak yang melaksanakan. POB menjadi acuan atau pedoman bagi pegawai dalam melaksanakan kegiatan dan terhindar dari penyimpangan maupun tumpang tindih pekerjaan.

Mengapa harus ada POB? POB telah diamanatkan dalam Peraturan Menteri Negara Pendayagunaan Aparatur Negara dan Reformasi Birokrasi nomor 35 tahun 2012 tentang pedoman penyusunan Standar Operasional Prosedur Administrasi Pemerintah (Indonesia, Peraturan Menteri Negara Pendayagunaan Aparatur Negara dan Reformasi Birokrasi nomor 35 tahun 2012 tentang pedoman penyusunan Standar Operasional Prosedur Administrasi Pemerintah, 2012). Amanat untuk menyusun POB juga tertuang dalam Peraturan Menteri Dalam Negeri RI nomor 52 tahun 2011 tentang Standar Operasional Prosedur di Lingkungan Pemerintah Provinsi dan Kabupaten/Kota (Indonesia, Peraturan Menteri Dalam Negeri RI nomor 52 tahun 2011 tentang Standar Operasional Prosedur di Lingkungan Pemerintah Provinsi dan Kabupaten/Kota, 2011). Dari sudut pandang bidang akuntansi, POB sebagai bagian dari usaha organisasi untuk melindungi asetnya dan sarana berkomunikasi dan menyampaikan informasi bagi pihak-pihak yang terkait.. Pemerintah Kuba, menyusun sistem pengembangan sumber daya manusia melalui penyusunan pengendalian internal yang terintegrasi (Cruz, 2018).

Rumah Sakit mitra kegiatan ini merupakan rumah sakit yang dikembangkan oleh institusi pendidikan sebagai salah satu penyelenggara administrasi pelayanan publik yang harus menyelenggarakan administrasi keuangan yang efektif, efisien dan bertanggungjawab. Ketiga hal terakhir ini dapat terpenuhi dengan memberikan suatu panduan yang jelas, sederhana dan tepat sasaran. Untuk bidang keuangan, dibutuhkan panduan mengenai kegiatan yang terkait dengan penatausahaan pendapatan, penatausahaan belanja operasional, penatausahaan belanja modal, penatausahaan tagihan dan hutang, serta penatausahaan belanja pegawai. Untuk bidang lainnya, tentunya dibutuhkan POB lain yang bersifat teknis, dan akan disusun secara bertahap. 


\section{METODE}

Kegiatan ini dilaksanakan dengan menggunakan metode tanyajawab dan pengamatan. Untuk kegiatan tanya-jawab dan pengamatan akan melibatkan pegawai mitra yang bertugas di bidang pengelolaan keuangan. Tanya-jawab dan pengamatan digunakan untuk memperoleh gambaran mengenai tugas individu, dokumen yang tersedia serta memperkirakan waktu yang digunakan dalam setiap jenis kegiatan. Kegiatan telah dilaksanakan bertahap sejak bulan Mei 2020 hingga Agustus 2020, yang meliputi pengumpulan data dan penyusunan draft POB.

\section{HASIL DAN PEMBAHASAN}

Langkah awal sebelum penyusunan $\mathrm{POB}$ adalah mengumpulkan informasi mengenai tugas pokok pegawai bidang keuangan. Tugas pokok diturunkan dari struktur organisasi rumah sakit mitra. Penyusunan POB bidang keuangan RSXX dimulai dari memahami konteks - apa yang telah dilakukan - selama kegiatan operasional berlangsung. Penyusunan POB ini tidak dimulai dari apa yang seharusnya namun dimulai dari apa yang telah dilakukan. Keputusan ini dibuat dengan asumsi bahwa POB telah ada atau telah dilaksanakan secara lisan atau karena terbiasa melakukan kegiatankegiatan yang tercantum dalam dokumen perencanaan dan realisasi. Berdasarkan struktur organisasi pada gambar 1, POB kegiatan bidang keuangan, meliputi: penerimaan kas, belanja operasional, belanja modal, piutang pihak ketiga (pencatatan dan penagihan), pelaporan dan pertanggungjawaban. Pegawai mitra yang terlibat dalam kegiatan tersebut terdiri dari 10 orang yang tersebar dalam rangkaian kegiatan penerimaan kas hingga pertanggungjawaban keuangan. Berdasarkan uraian kegiatan yang dilaksanakan oleh pegawai mitra inilah rancangan $\mathrm{POB}$ mulai disusun.

Rancangan POB dari setiap kegiatan disusun dari jawaban pegawai mitra atas pernyataan: jelaskan hal atau kegiatan apa saja yang telah anda lakukan selama bekerja di bagian keuangan rumah sakit ini. Petikan jawaban atas pertanyaan tersebut terlihat pada gambar 2. Berdasarkan jawaban mereka inilah disusun rancangan POB sebagaimana disajikan di lampiran. 


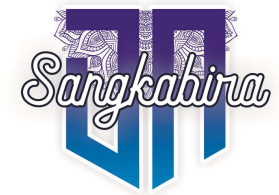

Vol. 1, No. 1, Desember 2020

Gambar 1. Petikan Jawaban Pegawai Mitra. Sumber: data primer, diolah.

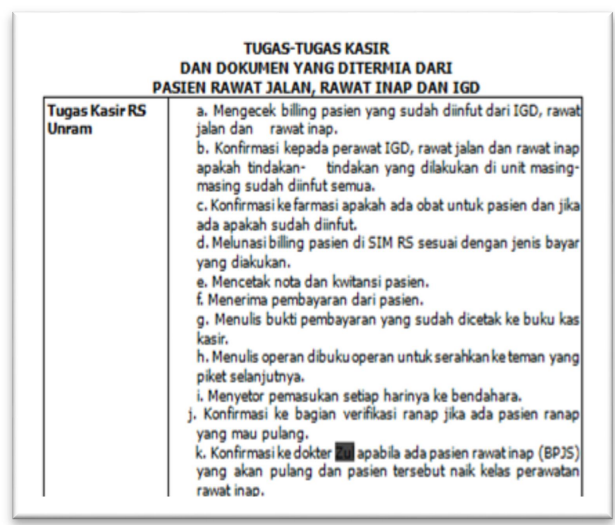

TUPOKSI BAGIAN KEUANGAN RS UNIVERSITAS MATARAM

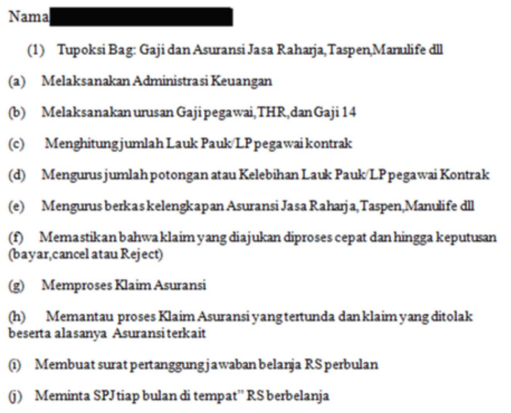

\begin{tabular}{|c|c|}
\hline $\mathrm{NO}$ & Tupoksi Bend.Pengeluaran: \\
\hline & 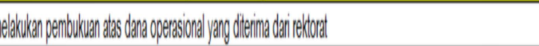 \\
\hline & 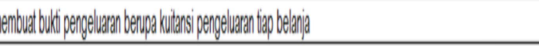 \\
\hline & 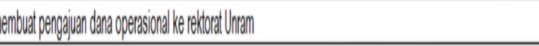 \\
\hline & 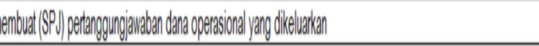 \\
\hline & 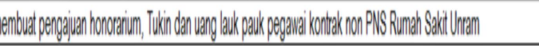 \\
\hline & 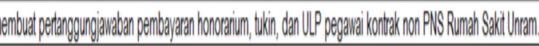 \\
\hline & 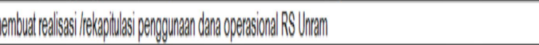 \\
\hline & 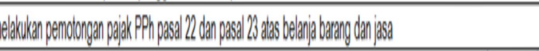 \\
\hline
\end{tabular}

1. Mengambil/menerimasetoran dan kuitansi pasienumum dari kasir

2. Menerimakuitansibililing pasien JPKMK darikasir

3. Merekap pemasukan pasien umum dan JPKMK

4. Mengklaim biaya berobat pasien JPKMK ke polikininik Universitas Mataram

5. Membuat surat permintaan pencairan dana dari pihak ketiga (asuransi, kerjasama) maupun

pembayaran pasien melaluimesin edcyang ditujukan kepada Rektor UNRAM

6. Menerima cek daribendahara rektorat dan mencairkan di bank

7. Menyetor pemasukan umum dan.JPkMKke bank

8. Mengarsipdokumen

9. Menyiapkanuang keciluntukkasi

10. Menerimatagihan

11. Membayar rujukan lab, transfuse darah, fee untukdriver ambulance perjuju

12. Menghitung dan membayar jaspeld dokter (mulaijaspeldesember dihitung dr. Rian)

13. Membantudalam pembuatan rekening bankuntuk karyawan bary
TUGASPOKOKDAN FUNGSIBAGIAN PERENCANAAN

A. Tugas Pokok

MenerimaUsulan Rencana Kuangan dari Pengelola Rumah sakit untuk disusun dan diajukan ke Rektorat/Kementerian

2. Membuat RBA, RAB, TOR, Mencaridata dukung dan Mengkompliasikedalam system RKAKL. dan E-TOR untuk dilinputdi sirenang rumah sakit segalausulan operasional rumah sakit dalan satutahun kedepan.

3. Membuatlaporan pemasukkan dan pengeluaran rumah sakit

4. Membuat berkas belanjar rumah sakkt yang melalui $L S$, Catalog dan PL bukan tender.

5. Membantu bagian umum dalam pembelanjaan barang kebutuhan rumah sakit.

B. Fungsi

1. Memastikan usulan rumah sakit sudah sesuaidengan peraturan yang ditetapkan oleh presiden dalam buku penggunaan dana/ standard biaya masukan yang sudah ditetapkan kementerian Keuangan.

2. Menyiapkan segala bentuk data pendukung (RBA, RAB, TOR, Sistem RKAKL dan E TOR) untuk usulan rencana penggunaan dana yang sudah sesuai dan yang dingginkan oleh rumah sakit. Melakukan hubungan dan koordinasidengan bidang terkaitd i rektoratuntukmembantu kelancaran proses realisasi operasional rumah sakit.

4. Mengkoordinassikan laporan Keuangan dengan unitterkat mengenaipenerimaan dan pengeluaran dana dirumah sakit kemudian untuk diliaporkan kepada kepala bagian Keuangan

Membuat berkas hasil belanja melalui $L$ S, Catalog dan PL bukan tender atas permintaan Universtas Mataram bukan rumah sakit. (Sk Rektor langsung)

6. Pergi belanja kebutuhan umum sesua i perintah kepala bagian umum.

10 TIGAS TMIMI

1 Menyusun RAB ATK dan barang kebutuhan numah sakit Tahun 2019:

2 Mengelola data obat dan bahan habis pakai (BHP) rumah sakit yang masuk ke aplikasi persediaan barang. 3 Mengelola data obat dan bahan habis pakai (BHP) numah sakit yang ketuar ke aplikasi persediaan barang: 4 Melakukan stok opname obat dan bahan habis pakai (BHP) numah sakit,

5 Mengelola data ATK dan barang rumah sabit yang masuk ke aplikasi persediaan barang:

6 Mengelola data ATK dan barang numah sakit yang keluar ke aplikasi persediaan barang:

7 Melakukan stok opname ATK dan barang rumah sakit,

8 Menginventaris Barang Nilik Negara (BMM) dir nmah sakit,

9 Metakukan pengkodean Barang Vilik Negara yang ada di numah sakit,

10 Mengrimm menerima email yang berkatan dengan segala kepentingan numah salk't;

11 Menerima dan mengarsipkan dokmmen penting yang berkanaan dengan dokumen numah sakit,

12 Membuat surat keluar yang berkatian dengan kebuthanan rumah sakit.

\section{POB menjadi dasar bagi pihak manajemen atau pengelola dalam mengukur kinerja individu maupun unit.}


Ketidaktersediaan dokumen POB bidang keuangan di rumah sakit mitra bukanlah suatu kesengajaan, namun melalui proses pembelajaran yang cukup panjang. Faktor pembelajaran ini dilandasi oleh kegiatan layanan jasa dan operasional yang baru mulai berjalan pada tahun 2018 setelah mengalami masa-masa terombang-ambing dan galau. POB yang dirancang, masih dapat dievaluasi sesuai dengan perkembangan jenis layanan, bentuk pembayaran, perkembangan teknologi informasi dan peraturan lain yang terkait dengan bidang keuangan layanan rumah sakit, baik internal maupun eksternal.

\section{KESIMPULAN DAN SARAN}

POB yang dirancang ini, dikhususkan pada transaksi atau kegiatan yang terkait dengan bidang keuangan. Meskipun terbatas pada bidang keuangan, namun melibatkan bidang non-keuangan lainnya. Misalnya saja, pelaksanaan belanja modal, akan terkait dengan bidang layanan jasa rumah sakit, yaitu alat kesehatan, furniture dan komputer. Keterlibatan bidang non keuangan meliputi ketersediaan dokumen pendukung seperti surat permohonan pembelian barang yang disertai dengan lampiran atau daftar barang yang dibutuhkan, daftar hadir kegiatan, daftar hadir pegawai setiap bulan, surat undangan mengenai kegiatan yang akan dilaksanakan, surat penawaran barang dari pihak eksternal, dan dokumen lainnya yang diperlukan. Keterlibatan bidang non keuangan juga tidak terlepas dari kerjasama yang baik setiap pegawai yang bertugas, seperti input data pasien dan jasa layanan yang telah diberikan oleh admin rawat jalan atau admin rawat inap atau admin farmasi atau admin unit gawat darurat dan operasi. Selanjutnya, rancangan POB ini perlu ditindaklanjuti dan dievaluasi secara periodik.

\section{UCAPAN TERIMA KASIH}

Kami ucapkan terimakasih kepada mitra rumah sakit,. Pimpinan beserta jajarannya, atas kerjasama dan dukungan yang diberikan dalam melaksanakan kegiatan pengabdian pada masyarakat ini. Ucapan terima kasih juga dihaturkan bagi Lembaga Penelitian dan Pengabdian Kepada Masyarakat Universitas Mataram, dan setiap pihak yang turut membantu terlaksanannya kegiatan ini. 
Vol. 1, No. 1, Desember 2020

\section{DAFTAR PUSTAKA}

Alhamudin, $1428 \mathrm{H}$. Pendidikan Islam Modern ala Trimurti Pondok Modern Darussalam Gontor. At-Ta'dib, 3(2), pp. 203-231.

Anwar, M. I., 2004. Administrasi Pendidikan dan Manajemen Biaya Pendidikan. 2 ed. Bandung: Alfabeta.

Arifin, M., n.d. https://www.academia.edu/32685163/manajemen keuangan pondok pesantren. [Online] Available at: https://www.academia.edu/32685163/manajemen keuangan pondok pesantren [Accessed 11 Agustus 2019].

Indonesia, B. \& Indonesia, I. A., 2018. Pedoman Akuntansi Pesantren: Efekti per Mei 2018. 1 ed. Jakarta: Departemen Ekonomi Syariah Bank Indonesia.

Shiddiq, A., 2015. Tradisi Akademik Pesantren. Tadris, 10(2), pp. 218-229.

Subekti, A., n.a. Academia. [Online] Available at: https://www.academia.edu/12256839/KH. Imam Zarkasyi dan P emikiran Pendidikannya [Accessed 19 Agustus 2019].

Yasid, A. et al., 2018. Paradigma Baru Pesantren: Menuju Pendidikan Islam Transformatif. 1 ed. Yogyakarta: IRCiSoD. 